\title{
Sinanaerobacter Chloroacetimidivorans Sp. Nov., An Obligate Anaerobic Bacterium Isolated From Anaerobic Sludge
}

\section{Yixuan Bao}

Nanyang Normal University

Junwei Liu

Nanyang Normal University

Xuan Zhang

Nanyang Normal University

Peng Lei

Nanyang Normal University

Jiguo Qiu

Nanyang Normal University

Jian He

Nanyang Normal University

$\mathrm{Na}$ Li ( $\square$ nali_nynu@yeah.net)

Nanyang Normal University

\section{Research Article}

Keywords: 16S rRNA gene sequence, activated sludge, Sinanaerobacter chloroacetimidivorans sp. nov, taxonomy

Posted Date: May 28th, 2021

DOI: https://doi.org/10.21203/rs.3.rs-559814/v1

License: @ (i) This work is licensed under a Creative Commons Attribution 4.0 International License. Read Full License

Version of Record: A version of this preprint was published at Antonie van Leeuwenhoek on August 19th, 2021. See the published version at https://doi.org/10.1007/s10482-021-01627-2. 


\section{Abstract}

An obligate anaerobic bacterial strain (BAD-6 $6^{\top}$ ) capable of degrading acetochlor and butachlor was isolated from an anaerobic acetochlor-degrading reactor. Cells were Gram-positive, straight to gently curved rods with flagella. The major fermentation products in peptone-yeast (PY) broth were acetate and butyrate. The optimum temperature and $\mathrm{pH}$ for growth was $30^{\circ} \mathrm{C}$ and $7.2-7.5$, respectively. The major cellular fatty acids $(>10 \%)$ were $\mathrm{C}_{14: 0} \mathrm{FAME}, \mathrm{C}_{16: 0}$ FAME and cyc-9,10- $\mathrm{C}_{19: 0}$ DMA. Genome sequencing revealed a genome size of $4.80 \mathrm{Mb}, \mathrm{a} \mathrm{G}+\mathrm{C}$ content of $43.6 \mathrm{~mol} \%$ and 4741 protein-coding genes. The most closely related described species on the basis of 16S rRNA gene sequences was Anaerovorax odorimutans NorPut ${ }^{\top}$ in the order Clostridiales of the class Clostridia with sequence similarity of $94.9 \%$. The nucleotide identity (ANI) value and digital DNA-DNA hybridization ( $\mathrm{dDDH}$ ) between the genomes of strain BAD- $6^{\top}$ and Ana. odorimutans NorPut ${ }^{\top}$ are $70.9 \%$ and $15.9 \%$, respectively. Based on the distinct differences in phylogenetic and phenotypic characteristics between strain BAD- $6^{\top}$ and related species, Sinanaerobacter chloroacetimidivorans gen. nov., sp. nov. is proposed to accommodate the strain. Strain BAD-10 ${ }^{\top}$ is the type strain $\left(=\right.$ CCTCC AB $2021092^{\top}=$ KCTC $\left.72521^{\top}\right)$.

\section{Introduction}

Chloroacetamide herbicides, such as alachlor, acetochlor, pretilachlor, propisochlor, butachlor and propiochlor, are an important class of herbicides and widely used in agriculture. However, their large-scale use has led to a continuous increase in the amount of residues in the environment, which has caused a serious threat to the ecological environment and human health (Lerro et al. 2015; Luo et al. 2004; Seghers et al. 2003). Chloroacetamide herbicides are highly toxic to aquatic organisms, and their residues in the soil damage subsequent crop rotations, especially in sandy soils with low organic matter content (Kim et al. 2013; Li et al. 2013; Zhang et al. 2011b). Thus, study the microbial degradation of chloroacetamide herbicides is of importance. At present, many aerobic chloroacetamide herbicides-degrading bacterial strains have been isolated and the aerobic catabolism have been elucidated (Chen et al. 2014; Chu et al. 2016; Wang et al. 2015; Zhang et al. 2011a). However, there was little study on the anaerobic degradation of chloroacetamide herbicides.

In our previous study, an anaerobic sludge capable of efficiently degrading acetochlor was obtained through pressure acclimation using sediment collected from an abandoned herbicide manufacturing plant (Liu et al. 2020). A bacterial strain BAD-6 $6^{\top}$ was isolated from the acclimated activated sludge. The strain is obligate anaerobic and could efficiently degrade acetochlor and butachlor. Based on the analysis of $16 \mathrm{~S}$ rRNA gene sequence, the strain was assigned to the class Clostridia in the phylum Firmicutes order Clostridiales. In this study, polyphasic taxonomic approach was carried out to determine the taxonomic position of strain BAD-6 ${ }^{\top}$.

\section{Materials And Methods}


Strain BAD- $6^{\top}$ was isolated from a continuous flow anaerobic reactor treating wasterwater containing acetochlor. The initial sludge sample collected from an abandoned herbicide manufacturing plant in

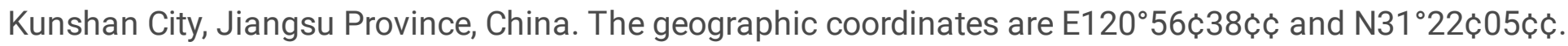
The medium for isolation was composed of the following (PYT): peptone $(0.5 \mathrm{~g})$, yeast extract $(1.0 \mathrm{~g})$, tryptone $(0.5 \mathrm{~g})$, acid hydrolysed casein $(1.0 \mathrm{~g})$, soluble starch $(1.0 \mathrm{~g})$, glucose $(1.0 \mathrm{~g}), \mathrm{K}_{2} \mathrm{HPO}_{4}(0.6 \mathrm{~g})$, $\mathrm{MgSO}_{4}(0.2 \mathrm{~g})$, sodium pyruvate $(0.6 \mathrm{~g})$, L-cysteine hydrochloride $(0.20 \mathrm{~g})$, resazurin $(1.0 \mathrm{mg})$, trace element solution $(1.0 \mathrm{ml})$, and vitamin solution $(1.0 \mathrm{ml})$ in $1.0 \mathrm{~L}$ distilled water. The $\mathrm{pH}$ value was adjusted to 7.2 using $50 \mathrm{mM} \mathrm{NaH} \mathrm{PO}_{4} / \mathrm{Na}_{2} \mathrm{HPO}_{4}$. The solutions of trace elements solution and vitamins solution are formulated as described by Widdel et al. (1983). For solid medium, $18 \mathrm{~g} \mathrm{~L}^{-1}$ agar was added. The medium was boiled and put into a serum bottle full with nitrogen (purity, $99.999 \%$ ) as the headspace to ensure anaerobic conditions. Then the serum bottle was sealed with rubber stopper. After autoclaving, the medium was supplemented with a sterile vitamin solution. The anaerobic sludge taken from the reactor was diluted, and $100 \mu \mathrm{L}$ of each dilution was spread onto the PYT agar plate in an anaerobic chamber (COY-7000220A, COY Laboratory Products Inc, Michigan, USA). Unless indicated otherwise, all the strains were anaerobically cultured on PYT at $37^{\circ} \mathrm{C}$. The strain was preserved at $-80^{\circ} \mathrm{C}$ in PYT broth supplemented with $20 \%(\mathrm{v} / \mathrm{v})$ glycerol.

\section{PCR Assay}

PCR amplification of the 16S rRNA gene was performed with the universal primers 27F and 1492R (Frank et al. 2008). The PCR product was purified by the PCR gel extraction kit (Omega Bio-Tek) and inserted into pMD19-T vector (TaKaRa Biotechnology). The inserted fragment was sequenced using an automated sequencer (model 3730, Applied Biosystems). The 16S rRNA gene sequences were compared with known sequences in GenBank of the NCBI (www.ncbi.nlm.nih.gov/BLAST/) and in EzBioCloud's identify service (www.ezbiocloud.net/identify). Sequence alignment was performed using the CLUSTAL_W program. Phylogenetic trees were reconstructed by the neighbor-joining (NJ) (Saitou and Nei 1987), maximumlikelihood (ML) (Felsenstein 1981) and minimum-evolution (ME) (Fitch 1971) algorithms, using the MEGA software (version 7.0) with Kimura's two-parameter calculation model (Kimura 1980). The topologies of the phylogenetic trees were assessed by bootstrap analysis of 1000 replications (Felsenstein 1985).

\section{Chemotaxonomic Characterization}

For genomic sequencing, the total DNA of strain BAD- $6^{\top}$ was extracted according to the method described by Sambrook et al. (1989). The draft genome of strain BAD- $6^{\top}$ was sequenced by Illumina Hiseq 4000 platform at Shanghai Biozeron Biotechnology Co., Ltd (Beijing, PR China). Paired end libraries with average insert length of $350 \mathrm{bp}$ were constructed; then, 100x libraries were obtained from clean paired end read data. Raw sequencing data assembly was performed using SOAPdenovo version 2.04 (Luo R et al. 2012). The assembled genomes were annotated with the Rapid Annotation with Subsystem Technology (RAST) server (Aziz RK et al. 2008). The genomic sequences of Anaerovorax odorimutans NorPut ${ }^{\top}$, Aminipila $^{2}$ butyrica $\mathrm{FH} 042^{\top}$ and Eubacterium brachy ATCC $35585^{\top}$ were obtained from the NCBI database. Comparative genomic analysis was carried out by the compare-function-based tool of the Seed Viewer 
(Overbeek $R$ et al. 2014). To further clarify the taxonomic relationship between strain BAD- $6^{\top}$ and its closest relatives Ana. odorimutans NorPut $^{\top}$ (Matthies et al. 2000), Ami. butyrica $\mathrm{FHO42}^{\top}$ (Ueki et al. 2018) and $E$. brachy ATCC $35585^{\top}$ (Holdemqn et al. 1980), average nucleotide identity (ANI) values and digital DNADNA hybridization ( $\mathrm{dDDH}$ ) between BAD- $6^{\top}$ and the three trype strains were calculated using the OrthoANlu algorithm (https://www.ezbiocloud.net/tools/ani) (Yoon et al. 2017) and genome-to-genome distance calculator (http://ggdc. dsmz.de/ggdc.php/) (Chun J et al. 2018), respectively. The DNA G+C content was determined from the genome sequence.

\section{Morphological, Physiological, and Biochemical Characterization}

For morphological characterization, BAD- $6^{\top}$ was observed using transmission electron microscopy $(\mathrm{H}-7650$; Hitachi) at exponential cells. Motility of cells was tested using the hanging-drop method (Bernardet et al. 2002). Endospore formation was determined as previously described by Logan et al. (2009) Growth of the strain under aerobic conditions was examined as described previously (Ueki et al. 2009). The Gram-stain was performed using the method described by Beveridge et al. (2007). To analyze the biochemical and physiological characteristics, strain BAD $-6^{\top}$ was cultivated in PYT broth at $37^{\circ} \mathrm{C}$. Growth at different temperatures $\left(10,15,25,28,30,37,42,45\right.$ and $\left.50^{\circ} \mathrm{C}\right)$, different $\mathrm{NaCl}$ concentrations $(0,0.5,1.0,2.0,3.0,4.0$ and $5.0 \%, \mathrm{w} / \mathrm{v}$ ) and different $\mathrm{pH}$ values ( $\mathrm{pH} 4.0-10.0$ at intervals of $0.5 \mathrm{pH}$ units) were assessed. Growth was monitored by measuring the $\mathrm{OD}_{600}$. For determination of salt tolerance, the PYT broth was adjusted to different $\mathrm{NaCl}$ concentrations. For estimating the $\mathrm{pH}$ range, the $\mathrm{PYT}$ broth was adjusted prior to sterilization using citrate/ $\mathrm{Na}_{2} \mathrm{HPO}_{4}$ buffer ( $\left.\mathrm{pH} 4.0-5.0\right), \mathrm{Na}_{2} \mathrm{HPO}_{4} / \mathrm{NaH}_{2} \mathrm{PO}_{4}$ buffer $(\mathrm{pH} 6.0-8.0)$ and glycine/ $\mathrm{NaOH}$ buffer (pH 9.0-10.0).

Mineral salt medium (MSM) (Liu et al. 2020) was used to determine the abilities of strain BAD- $6^{\top}$ to degrade acetochlor and butachlor. The strain BAD- $6^{\top}$ was inoculated into MSM supplemented with acetochlor or butachlor $(50 \mu \mathrm{M})$. Then the serum bottle was shaken on a rotary shaker at $37^{\circ} \mathrm{C}$ and 150 $\mathrm{rpm} / \mathrm{min}$. Each treatment was performed in triplicate, and the control group without strain BAD- $6^{\top}$ was set under the same conditions. After incubation for 14 days, the culture was sampled to determine the concentrations of acetochlor and butachlor by HPLC as described by Liu et al. (2020).

The main organic acids products of peptone-yeast extract (PY) medium fermentation were detected using HPLC as described by Zhang et al. (2018). Other enzymatic activities and utilization of various carbon sources were investigated using commercial kits (API 20NE, API ZYM and API 50CH) and Biolog GENIII MocroPlate according to the manufacturers' protocols. Determination of the respiratory quinone system was performed as described previously (Collins et al., 1977). For analysis of fatty acids, cells of strain BAD$6^{\mathrm{T}}$ were cultured in PYT broth at $37^{\circ} \mathrm{C}$ in the exponential phase. Cellular fatty acids were saponified, methylated and extracted as described previously, which was performed by using the Sherlock MIS (MIDI) system.

\section{Results And Discussion}




\section{Phylogenetic characterisation}

An almost-complete 16S rRNA gene sequence of strain BAD- $6^{\top}$ (1527 bp) was acquired. Comparative analysis of $16 \mathrm{~S}$ rRNA gene sequences assigned strain BAD- $6^{\top}$ to the class Clostridia in the phylum Firmicutes. Strain BAD-6 ${ }^{\top}$ was closely related to Ana. odorimutans NorPut $^{\top}$ (similarity $94.9 \%$ ), Ami. butyrica $\mathrm{FH042}{ }^{\top}(94.4 \%)$ and $E$. brachy ATCC $35585^{\top}(90.5 \%)$. The $16 \mathrm{~S}$ rRNA gene sequences similarities between BAD- $6^{\top}$ and Ana. odorimutans NorPut $^{\top}$ (94.9\%), Ami. butyrica $\mathrm{FHO}^{2} 2^{\top}$ (94.4\%), E. brachy ATCC $35585^{\top}(90.5 \%)$ were below the threshold value for defining bacterial genera $(95.0 \%)$ recommended by Yarza et al. (2014). In the phylogenetic tree based on the NJ algorithm, strain BAD- $6^{\top}$ formed a separate branch (Fig 1), and the overall membership was also supported by the ML and ME trees (Fig S1 and S2). These results indicated that strain BAD- $6^{\top}$ might represent a novel genus.

\section{Genomic characterisation}

The draft genome of strain BAD- $6^{\top}$ consisted of 69 contigs and the $\mathrm{N} 50$ length was $0.20 \mathrm{Mb}$. Comparative

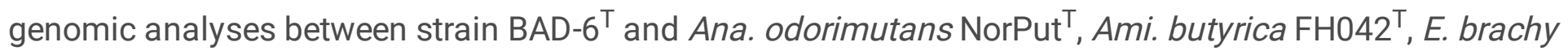
ATCC $35585^{\top}$ were conducted (Table 1 and Fig. S3). The size of the genome and the number of proteincoding genes of strain BAD- $6^{\top}$ were $4.80 \mathrm{Mb}$ and 4741 , respectively. The size of the genome and the number of protein-coding genes from strain BAD- $6^{\top}$ were much larger than those of Ana. odorimutans NorPut $^{\top}$ (3.26 Mb and 3062, respectively), Ami. butyrica $\mathrm{FHO}^{\top}{ }^{\top}$ (3.33 $\mathrm{Mb}$ and 3199 , respectively) and $E$. brachy ATCC $35585^{\top}$ (1.54 Mb and 1464, respectively). In addition, the numbers of RNAs of strain BAD- $6^{\top}$ (54) were much larger than those of Ana. odorimutans $\operatorname{NorPut}^{\top}(45)$ and E. brachy ATCC $35585^{\top}$ (37), and were lower than those of Ami. butyrica $\mathrm{FHO42}^{\top}$ (83).

In the characteristics of subsystems (subsystem coverage and sub-system category distribution), the genomes between strainBAD- $6^{\top}$ and Ana. odorimutans NorPut $^{\top}$, Ami. butyrica $\mathrm{FH} 042^{\top}$, E. brachy ATCC $35585^{\top}$ were significant different. Most of the annotated genes of strain BAD- $6^{\top}$ were responsible for the cofactors, vitamins, prosthetic groups, pigments (136), protein metabolism (142), amino acids and derivatives (295) and carbohydrates (309) (Table 1 and Fig. S3). The number of genes presumed to be involved in cofactors, vitamins, prosthetic groups, pigments; amino acids and derivatives and carbohydrates were higher than those of Ana. odorimutans $\mathrm{NorPut}^{\top}$, Ami. butyrica $\mathrm{FHO42}^{\top}$ and E. brachy ATCC $35585^{\top}$; while the number of genes presumed to be involved in membrane transport, protein metabolism and RNA metabolism were similiar with Ana. odorimutans $\mathrm{NorPut}^{\top}$ and $\mathrm{Ami}$. $\mathrm{FHO42}^{\top}$, and were much larger than those of E. brachy ATCC $35585^{\top}$.

The ANI values obtained between the genomes of strain BAD- $6^{\top}$ and Ana. odorimutans NorPut $^{\top}$, Ami. butyrica $\mathrm{FHO42}{ }^{\top}$, E. brachy ATCC $35585^{\top}$ were $70.9 \%, 68.1 \%$, and $66.8 \%$, respectively (Table S1). The dDDH between strain BAD- $6^{\top}$ and the three related type strains were $15.9 \%, 17.3 \%$, and $19.3 \%$, respectively (Table S1). All these data were below the $80 \%(\mathrm{ANI})$ and $20 \%(\mathrm{dDDH})$ thresholds (Rodriguez R. and Konstantinidis 2014; Zhang and Huang 1990), which were recommended for describing a novel bacterial genus. 


\section{Phenotypic and Physiological Characteristics}

Colonies of strain BAD- $6^{\top}$ were faint yellow with a smooth surface on PYT agar after incubation for 2 days. Cells were Gram-stain-positive and straight or slightly curved rods, and $0.3-0.5 \mu \mathrm{m}$ in diameter and 1.8-2.5 $\mu \mathrm{m}$ in length. Cells were motile with one or two peritrichous flagella (Fig. S4). The strain could not grow aerobically and could not product spores. The temperature range for growth was $16-42{ }^{\circ} \mathrm{C}$ with the highest growth rate at $30^{\circ} \mathrm{C}$. The strain grew at $\mathrm{pH} 6.3-8.0$ with optimum being $\mathrm{pH} 7.2-7.5$. The strain has the highest growth rate without adding $\mathrm{NaCl}$ in PYT broth. Strain BAD- $6^{\top}$ could degrade $98.2 \%$ acetochlor and $67.4 \%$ butachlor after inocubation for 14 days.

\section{Chemotaxonomic characterisation}

The strain produced acetate and butyrate after incubation for 3 days in PY medium. Strain BAD- $6^{\top}$ could utilize carbohydrates and organic acids (D-cellobios, gentiobiose, D-turanose, D-melibiose, a-D-glucose, Dmannose, D-fructose, D-galacturonic acid, L-galactonic acid lactone, D-glucuronic acid, glucuronamide, tetrazolium violet, D-galactose, 3-methyl glucose, D-fucose, L-fucose, L-rhamnose, D-glucose-6-phosphate, D-fructose-6-phosphate, and sodium butyrate). Strain BAD-6 ${ }^{\top}$ could only use serine for growth. Catalase, oxidase, nitrate-reducing activities, and indole production were not detected. Strain BAD- $6^{\top}$ could hydrolyse esculin but not urea or gelatin. The strain were positive for activities of alkaline phosphatase, acid phosphatase, and naphthol-AS-BI-phosphohydrolase. In addition, esterase (C4) and leucine arylamidase were weakly positive. No substances could be used by BAD- $6^{\top}$ as detected in the API $50 \mathrm{CH}$ system.

The major fatty acids $(>10 \%)$ of strain BAD- $6^{\top}$ were $\mathrm{C}_{14: 0}$ FAME $(15.12 \%), \mathrm{C}_{16: 0}$ FAME $(16.69 \%)$ and cyc9,10- $\mathrm{C}_{19: 0}$ DMA (10.13\%). In addition, small amounts $(>5.0 \%)$ of iso- $\mathrm{C}_{15: 0}$ FAME (5.18\%), cis-7- $\mathrm{C}_{16: 1}$ FAME (6.87\%), and $\mathrm{C}_{16: 0}$ DMA (8.09\%) were also detected in strain BAD- $6^{\top}$ (Table S2). However, respiratory quinone was not detected in strain BAD-6 ${ }^{\top}$.

\section{Taxonomic Conclusion}

Some characteristics of the strain BAD- $6^{\top}$ were compared with its neighboring genus (Table 2). Strain BAD$6^{\top}$ can utilize carbohydrates and D-serine, and has flagella, while the Ana. odorimutans NorPut ${ }^{\top}$ can not use any carbohydrates or amino acids and has 3-5 flagella. In addition, the $\mathrm{G}+\mathrm{C}$ content of strain BAD- $6^{\top}$ (43.6 \%) was much more than that of Ana. odorimutans NorPut $^{\top}(31.5 \%)$. There were also some differences between strain $\mathrm{BAD}-6^{\top}$ and Ami. butyrica $\mathrm{FH} 042^{\top}$. e.g. Ami. butyrica $\mathrm{FH}^{-}{ }^{\top} 2^{\top}$ could not use any carbohydrates. Ami. butyrica $\mathrm{FH} 042^{\top}$ and $\mathrm{BAD}-6^{\top}$ could use different types of amino acids. The major fatty acids of strain BAD- $6^{\top}$ are $\mathrm{C}_{14: 0}$ FAME, $\mathrm{C}_{16: 0}$ FAME and cyc-9,10- $\mathrm{C}_{19: 0}$ DMA; while Ami. butyrica $\mathrm{FH} 042^{\top}$ are

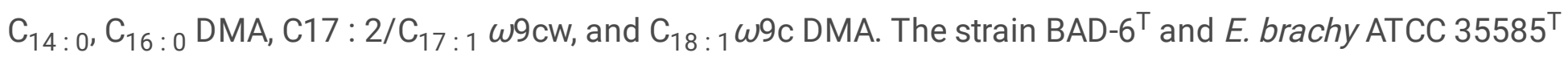
are also different in morphology, physiology and biochemistry, such as cell size, cell morphology, and carbohydrate utilization. It is worth noting that the similarities of $16 \mathrm{~S}$ rRNA genes between the strain BAD$6^{\top}$ and other type strains are less than $95 \%$ and the phylogenetic trees of BAD- $6^{\top}$ forms a separate branch with type strains based on the NJ, ML and ME algorithm. 
In summary, phylogenetic analysis shows that strain BAD- $6^{\top}$ belongs to a novel genus. Due to cell morphology, growth temperature, carbon source assimilation, DNA G + C content and fatty acid profile, the BAD-6 strain can be clearly distinguished from other strains (Table 2). In addition, the ANI and dDDH values between the strain BAD- 6 and Ana. odorimutans NorPut ${ }^{\top}$, Ami. butyrica $\mathrm{FH} 042^{\top}$, E. brachy ATCC $35585^{\top}$ were significantly lower than the recommended cut-off values for the species boundary. Thus, based on the data, we propose the novel genus Sinanaerobacter gen. nov. in the order Clostridiales to accommodate strain BAD-6 ${ }^{\top}$ as Sinanaerobacter chloroacetimidivorans.

\section{Description of Sinanaerobacter gen. nov.}

Sinanaerobacter $₫$ M.L. fem. n. Sina China; Gr. pref. an- not; Gr. masc. n. aer air; N.L. masc. n. bactera rod; N.L. masc. n. Sinanaerobacter an anaerobic rod from China).

Obligate anaerobic, motile rods. Gram-stain-positive. Utilize carbohydrates and D-serine. Oxidase and catalase activities are negative. Compounds even-numbered fatty acids or fatty acid methyl esters are major components of cellular fatty acids. Does not have any respiratory quinones. The genus belongs to the order Clostridium.

The type species is Sinanaerobacter chloroacetimidivorans.

\section{Description of Sinanaerobacter chloroacetimidivorans gen., nov. sp. nov.}

Sinanaerobacter chloroacetimidivorans (chlo.ra.ce.ti.mi.di.vo'rans. N.L. neut. n. chloracetimidum chloracetimide; L. pres. part. Vorans eating; N.L. part. adj. chloracetimidivorans eating chloracetimide).

Cells are straight to gently curved rods with flagella, $0.3-0.5 \mu \mathrm{m}$ in diameter and 1.8-2.5 $\mu \mathrm{m}$ in length, and motile with peritrichous flagella. Spore formation is not observed. Colonies on PYT agar are faint yellow with a smooth surface. B-vitamins are not required for growth. Grows at $16-42{ }^{\circ} \mathrm{C}$ (optimum $30^{\circ} \mathrm{C}$ ), $\mathrm{pH}$ 6.3-8.0 (optimum pH 7.2-7.5) and $0-5 \% \mathrm{w} / \mathrm{v} \mathrm{NaCl}$ (optimum $0 \% \mathrm{w} / \mathrm{v}$ ) were observed. Fermentation can produce acetate and butyrate in PY medium. Carbohydrates and organic acids (D-cellobios, gentiobiose, Dturanose, D-melibiose, a-D-glucose, D-mannose, D-fructose, D-galacturonic acid, L-galactonic acid lactone, D-glucuronic acid, glucuronamide, tetrazolium violet, D-galactose, 3-methyl glucose, D-fucose, L-fucose, Lrhamnose, D-serine, D-glucose-6-phosphate, D-fructose-6-phosphate, and sodium butyrate.) improve the strain growth. Only D-serine can be utilized. Does not utilize other amino acids (L-alanine, L-arginine, Laspartic acid, L-glutamic acid, L-histidine, L-pyroglutamic acid, L-serine and D-aspartic acid). Oxidase, catalase and nitrate-reducing activities are negative. Esculin is hydrolysed, but urea and gelatin are not hydrolysed. Indole and arginine dihydrolase are not produced. The strain is positive for activities of alkaline phosphatase, acid phosphatase, and naphthol-AS-BI-phosphohydrolase. In addition, esterase (C4) and leucine arylamidase are weakly positive. The genomic DNA G+C content is $43.6 \mathrm{~mol} \%$. $\mathrm{C}_{14: 0}$ FAME, $\mathrm{C}_{16: 0}$ FAME and cyc-9,10- $\mathrm{C}_{19: 0}$ DMA are detected as major components by the cellular fatty acid $(>10 \%)$ analysis. Does not have any respiratory quinones. 
The GenBank/EMBL/DDBJ accession numbers for the 16S rRNA gene sequences and the whole genome of strain BAD-6 $6^{\top}$ are MW727621 and JAGSND000000000, respectively. The type strain BAD-6 ${ }^{\top}$ (= CCTCC $\mathrm{AB} 2021092^{\top}=\mathrm{KCTC} 72521^{\top}$ ) was isolated from the anaerobic acetochlor-degrading sludge in Kunshan City, Jiangsu Province, China.

\section{Declarations}

\section{Funding information}

This work was supported by the National Natural Science Foundation of China (grant number 31900082).

\section{Authors contributions}

Conceptualization, funding acquisition, and supervision: Jian He and Na Li; Laboratory work, data analysis and writing-original draft: Yixuan Bao; Writing-review and editing: Junwei Liu, Xuan Zhang, Peng Lei, Jiguo Qiu. All authors read and approved the final manuscript.

\section{Availability of data and materials}

The GenBank/EMBL/DDBJ accession numbers for the 16S rRNA gene sequences and the whole genome of strain BAD-6 $6^{\top}$ are MW727621 and JAGSND000000000, respectively.

\section{Code availability}

Not applicable.

\section{Ethics declarations}

\section{Conflict of Interest}

The research was conducted in the absence of any commercial or financial relationships that could be construed as a potential conflict of interest. All the authors declare that they have no conflict of interest.

\section{Ethical Approval}

The authors have declared that no ethical issues exist.

\section{Research Involving Human and /or Animal Participants}

This article does not contain any studies with human participants or animals performed by any of the author.

\section{Consent to Participate and Consent for Publication}

All authors agree to have participated in the research proposed to be published and agree to be published in the journal. 


\section{Data availability}

All authors have declared that all data are availability.

\section{References}

1. Aziz RK, Bartels D, Best AA et al (2008) The RAST server: Rapid annotations using subsystems technology. Bmc Genomics 9:75

2. Beveridge T, Lawrence J, Murray R (2007) Sampling and staining for light microscopy. Methods for General and Molecular Microbiology, 3rd edn. American Society of Microbiology pp, pp 19-33

3. Chen Q, Zhang J, Wang CH et al (2014) Novosphingobium chloroacetimidivorans sp nova, a chloroacetamide herbicide-degrading bacterium isolated from activated sludge. Int J Syst Evol Microbiol 64:2573-2578

4. Chu CW, Chen Q, Wang CH, Wang HM, Sun ZG, He Q, He J, Gu JG (2016) Roseomonas chloroacetimidivorans sp nov., a chloroacetamide herbicide-degrading bacterium isolated from activated sludge. Antonie Van Leeuwenhoek 109:611-618

5. Chun J, Oren A, Ventosa A et al (2018) Proposed minimal standards for the use of genome data for the taxonomy of prokaryotes. Int J Syst Evol Microbiol 68:461-466

6. Collins MD, Pirouz T, Goodfellow M et al (1977) Distribution of menaquinones in actinomycetes and corynebacteria. J Gen Appl microbiol 100:221-230

7. Widdel F, Kohring G, Mayer F (1983) Studies on dissimilatory sulfate-reducing bacteria that decompose fatty acids. III. Characterization of the filamentous gliding Desulfonema limicola gen. nov., sp. nov., and Desulfonema magnum sp. nov. Arch Microbiol 183:286-293

8. Felsenstein J (1981) Evolutionary trees from DNA sequences: a maximum likelihood approach. J Mol Evol 17:368-376

9. Felsenstein J (1985) Confidence limits on phylogenies: an approach using the bootstrap. Evol 39:783791

10. Fitch WM (1971) Toward defining the course of evolution: minimum change for a specific tree topology. Syst Zool 20:406-416

11. Frank JA, Reich $\mathrm{Cl}$, Sharma $\mathrm{S}$ et al (2008) Critical evaluation of two primers commonly used for amplification of bacterial 16S rRNA genes. Appl Environ Microbiol 74:2461-2470

12. Holdemqn LV, Cato EP, Burmeister JA et al (1980) Descriptions of Eubacterium timidum sp. nov., Eubacterium brachy sp. nov., and Eubacterium nodatum sp. nov. isolated from human periodontitis. Int J Syst Evol Microbiol 30:163-169

13. Kim NH, Kim DU, Kim I et al (2013) Syntrophic biodegradation of butachlor by Mycobacterium sp J7A and Sphingobium sp J7B isolated from rice paddy soil. FEMS Microbiol Lett 344:114-120

14. Kimura M (1980) Evolutionary rates models. J Mol Evol 16:111-120

15. Lerro CC, Koutros S, Andreotti G, Hines CJ, Blair A, Lubin J, Ma X, Zhang Y, Beane Freeman LE (2015) Use of acetochlor and cancer incidence in the Agricultural Health Study. Int J Cancer 137:1167-1175 
16. Li Y, Chen Q, Wang CH, Cai S, He J, Huang X, Li SP (2013) Degradation of acetochlor by consortium of two bacterial strains and cloning of a novel amidase gene involved in acetochlor-degrading pathway. Bioresour Technol 148:628-631

17. Liu JW, Zhang X, Xu JY, Qiu JG, Zhu JC, Cao H, He J (2020) Anaerobic biodegradation of acetochlor by acclimated sludge and its anaerobic catabolic pathway. Sci Total Environ 748:141122

18. Luo HF, Qi HY, Zhang HX (2004) The impact of acetochl or the bacterial diversity in soil. Acta Microbiol 44:519-522

19. Luo R, Liu B, Xie Y et al (2012) SOAPdenovo2: an empirically improved memory-efficient short-read de novo assembler. Gigascience 1:18

20. Matthies C, Evers S, Ludwig W et al (2000) Anaerovorax odorimutans gen. nov., sp nov., a putrescinefermenting, strictly anaerobic bacterium. Int J Syst Evol Microbiol 50:1591-1594

21. Overbeek R, Olson R, Pusch GD et al (2014) The SEED and the Rapid Annotation of microbial genomes using Subsystems Technology (RAST). Nucleic Acids Res 42:D206-D214

22. Rodriguez R, Konstantinidis KTA (2014) Bypassing cultivation to identify bacterial species(Note). Microbe 9:111-118

23. Saitou N, Nei M (1987) The neighbor-joining method: a new method for reconstructing phylogenetic trees. Mol Biol Evol 4:406-425

24. Sambrook J, Fritsch E, Maniatis T (1989) Molecular Cloning: a Laboratory Manual, 3, 2nd edn. Cold Springs Harb Lab Press

25. Seghers D, Verthe K, Reheul D et al (2003) Effect of long-term herbicide applications on the bacterial community structure and function in an agricultural soil. FEMS Microbiol Ecol 46:139-146

26. Ueki A, Abe K, Suzuki D, Kaku N, Watanabe K, Ueki K (2009) Anaerosphaera aminiphila gen. nov., sp nov., a glutamate-degrading, Gram-positive anaerobic coccus isolated from a methanogenic reactor treating cattle waste. Int J Syst Evol Microbiol 59:3161-3167

27. Ueki A, Goto K, Kaku N et al (2018) Aminipila butyrica gen. nov., sp nov., a strictly anaerobic, argininedecomposing bacterium isolated from a methanogenic reactor of cattle waste. Int J Sys Evol Microbiol 68:443-448

28. Wang F, Zhou J, Li Z, Dong W, Hou Y, Huang Y, Cui Z (2015) Involvement of the Cytochrome P450 System EthBAD in the N-Deethoxymethylation of Acetochlor by Rhodococcus sp Strain T3-1. Appl Environ Microbiol 81:2182-2188

29. Yarza P, Yilmaz P, Pruesse E (2014) Uniting the classification of cultured and uncultured bacteria and archaea using 16S rRNA gene sequences. Nat Rev Microbiol 12:635-645

30. Yoon SH, Ha Sm, Lim J et al (2017) A large-scale evaluation of algorithms to calculate average nucleotide identity. Antonie Van Leeuwenhoek 110:1281-1286

31. Zhang J, Zheng J, Liang B et al (2011a) Biodegradation of Chloroacetamide Herbicides by Paracoccus sp FLY-8 in Vitro. J Agric Food Chem 59:4614-4621

32. Zhang J, Zheng JW, Liang B, Wang CH, Cai S, Ni YY, He J, Li SP (2011b) Biodegradation of chloroacetamide herbicides by Paracoccus sp FLY-8 in vitro. J Agri Food Chem 59:4614-4621 
33. Zhang JZ, Huang JJ (1990) Microbial taxonomy. Fudan University press, shanghai

34. Zhang X, Tu B, Dai Lr, Lawson PA, Zheng ZZ, Liu LY, Deng Y, Zhang H, Cheng L (2018) Petroclostridium xylanilyticum gen. nov., sp nov., a xylan-degrading bacterium isolated from an oilfield, and reclassification of clostridial cluster III members into four novel genera in a new Hungateiclostridiaceae fam. nov. Int J Syst Evol Microbiol 68:3197-3211

35. Bernardet JF, Nakagawa Y, Holmes B et al (2002) Proposed minimal standards for describing new taxa of the family Flavobacteriaceae and emended description of the family. Int J Syst Evol Microbiol 52:1049-1070

36. Logan NA, Berge O, Bishop AH et al (2009) Proposed minimal standards for describing new taxa of aerobic, endospore-forming bacteria. Int J Syst Evol Microbiol 59:2114-2121

\section{Tables}

Table 1 Comparison of genomic characteristics between BAD- $6^{\top}$ and the strains with higher genomic similarity. Strain: 1, BAD-6 ${ }^{\top} ; 2$, Anaerovorax odorimutans NorPut $^{\top} ; 3$, Aminipila butyrica FH042 ${ }^{\top} ; 4$, Eubacterium brachy ATCC $35585^{\top}$. 


\begin{tabular}{|c|c|c|c|c|}
\hline Characteristic & 1 & 2 & 3 & 4 \\
\hline $\begin{array}{l}\text { Number of } \\
\text { contigs }\end{array}$ & 69 & 57 & 1 & 27 \\
\hline $\begin{array}{l}\text { N50 value } \\
(\mathrm{Mb})\end{array}$ & 0.20 & 0.10 & 0 & 0.14 \\
\hline $\begin{array}{l}\text { Genome size } \\
(\mathrm{Mb})\end{array}$ & 4.80 & 3.26 & 3.33 & 1.54 \\
\hline $\begin{array}{l}\text { Protein- } \\
\text { coding genes }\end{array}$ & 4741 & 3062 & 3199 & 1464 \\
\hline RNAs & 54 & 45 & 83 & 37 \\
\hline $\begin{array}{l}\text { Accession } \\
\text { numbers }\end{array}$ & JAGSND000000000 & GCA_000426305 & GCA_010669305 & GCA_000488855 \\
\hline $\begin{array}{l}\text { Cofactors, } \\
\text { Vitamins, } \\
\text { Prosthetic } \\
\text { Groups, } \\
\text { Pigments }\end{array}$ & 136 & 100 & 63 & 64 \\
\hline $\begin{array}{l}\text { Cell Wall and } \\
\text { Capsule }\end{array}$ & 39 & 28 & 33 & 10 \\
\hline $\begin{array}{l}\text { Virulence, } \\
\text { Disease and } \\
\text { Defense }\end{array}$ & 53 & 60 & 49 & 30 \\
\hline $\begin{array}{l}\text { Potassium } \\
\text { metabolism }\end{array}$ & 6 & 2 & 5 & 1 \\
\hline Miscellaneous & 17 & 5 & 5 & 0 \\
\hline $\begin{array}{l}\text { Phages, } \\
\text { Prophages, } \\
\text { Transposable } \\
\text { elements, } \\
\text { Plasmids }\end{array}$ & 3 & 2 & 10 & 3 \\
\hline $\begin{array}{l}\text { Membrane } \\
\text { Transport }\end{array}$ & 54 & 44 & 30 & 45 \\
\hline $\begin{array}{l}\text { Iron } \\
\text { acquisition } \\
\text { and } \\
\text { metabolism }\end{array}$ & 5 & 8 & 7 & 0 \\
\hline $\begin{array}{l}\text { RNA } \\
\text { Metabolism }\end{array}$ & 50 & 48 & 37 & 24 \\
\hline $\begin{array}{l}\text { Nucleosides } \\
\text { and } \\
\text { Nucleotides }\end{array}$ & 96 & 91 & 51 & 29 \\
\hline Protein & 142 & 149 & 169 & 87 \\
\hline
\end{tabular}


Metabolism

Cell Division

and Cell Cycle

Motility and 28

3

3

3

Chemotaxis

Regulation 2

212

$\begin{array}{ll}7 & 0\end{array}$

0

and Cell

10

2

signaling

Secondary

Metabolism

DNA

Metabolism

Fatty Acids,

Lipids, and

Isoprenoids

Nitrogen

Metabolism

Dormancy 2

and

Sporulation

$\begin{array}{lll}\text { Respiration } & 38 & 39 \\ \text { Stress } & 31 & 18 \\ \text { Response } & & \end{array}$

Metabolism of 7

Aromatic

Compounds

Amino Acids 295

and

9

5

14

6

1

39

18

1

2

13

19

829

11

1

190

250

55

Derivatives

Sulfur

6

Metabolism

Phosphorus

Metabolism

Carbohydrates
13

309
4

7

83
4

26

111
51

22

0

(

11

0

55




\begin{tabular}{|c|c|c|c|c|}
\hline Characteristics & 1 & 2 & 3 & 4 \\
\hline $\begin{array}{l}\text { Isolation } \\
\text { source }\end{array}$ & anaerobic sludge & $\begin{array}{l}\text { anoxic } \\
\text { brackish } \\
\text { water } \\
\text { sediments }\end{array}$ & $\begin{array}{l}\text { methanogenic reactor } \\
\text { of cattle waste }\end{array}$ & Human Periodontitis \\
\hline Gram staining & + & + & + & + \\
\hline Cell shape & $\begin{array}{l}\text { straight to gently } \\
\text { curved rods }\end{array}$ & $\begin{array}{l}\text { slightly } \\
\text { curved rods }\end{array}$ & $\begin{array}{l}\text { Straight to gently } \\
\text { curved rods }\end{array}$ & coccoid/rods \\
\hline Cell size $(\mu \mathrm{m})$ & $0.3-0.5 ' 1.8-2.5$ & $\begin{array}{l}0.7-0.8 \\
1.9-2.7\end{array}$ & $0.7-1.0 ` 3.0-40$ & $0.4-0.8^{\prime} 1.0-3.0$ \\
\hline Motility & + & + & + & - \\
\hline Spore & - & - & - & - \\
\hline $\begin{array}{l}\text { Temperature } \\
\text { range } \\
\text { (optimum) ( } \\
{ }^{\circ} \mathrm{C} \text { ) }\end{array}$ & $16-42(30)$ & $12-50(30)$ & $\begin{array}{l}10-35 \\
(30)\end{array}$ & 37 (optimum) \\
\hline $\begin{array}{l}\mathrm{pH} \text { growth } \\
\text { range } \\
\text { (optimum) }\end{array}$ & $6.3-8.0(7.2-7.5)$ & $\begin{array}{l}5.1-8.0 \\
(7.2-7.6)\end{array}$ & $5.3-8.2(6.1-6.8)$ & NR \\
\hline Carbohydrates & + & - & - & NR \\
\hline Amino acids & D-serine & - & $\begin{array}{l}\text { L-Arginine, L-Lysine, L- } \\
\text { Serine }\end{array}$ & NR \\
\hline $\begin{array}{l}\text { PY } \\
\text { Fermentation } \\
\text { acid } \\
\text { production }\end{array}$ & acetate, butyrate & $\begin{array}{l}\text { acetate, } \\
\text { butyrate }\end{array}$ & acetate, butyrate & $\begin{array}{l}\text { isovalerate, } \\
\text { isobutyrate, acetate, } \\
\text { formate, succinate }\end{array}$ \\
\hline Major CFAs & $\begin{array}{l}\mathrm{C}_{14: 0} \text { FAME, } \mathrm{C}_{16: 0} \\
\text { FAME, cyc-9,10- } \\
\mathrm{C}_{19: 0} \text { DMA }\end{array}$ & NR & $\begin{array}{l}\mathrm{C}_{14: 0}, \mathrm{C}_{16: 0} \text { DMA, C17 } \\
: 2 / \mathrm{C}_{17: 1} \omega 9 \mathrm{cw}, \mathrm{C}_{18}: \\
{ }_{1} \omega 9 \mathrm{c} \text { DMA }\end{array}$ & NR \\
\hline $\begin{array}{l}\text { Genomic DNA } \\
\text { G+C content } \\
\text { (mol\%) }\end{array}$ & 43.6 & 31.5 & 44.7 & 37.9 \\
\hline
\end{tabular}

\section{Figures}




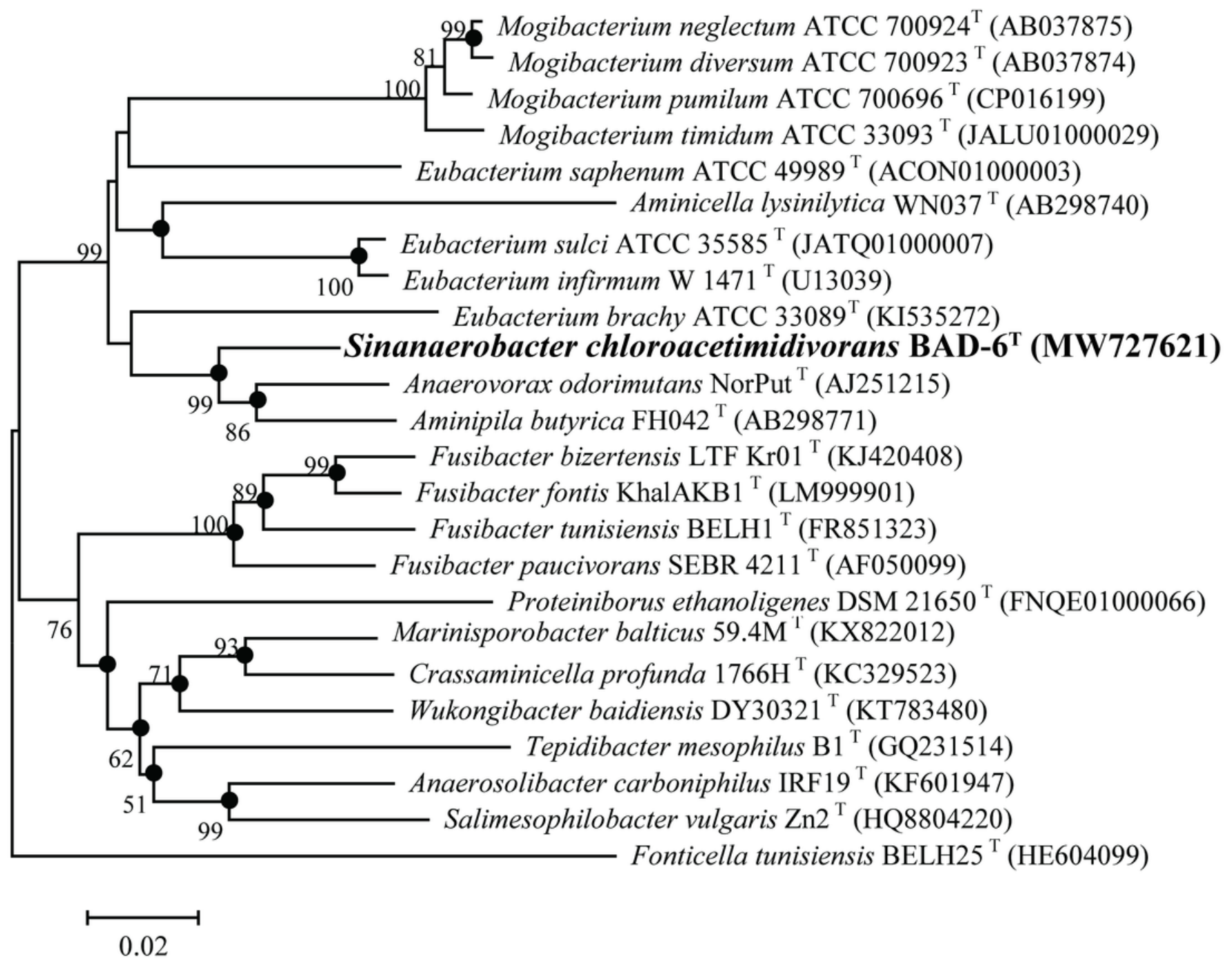

Figure 1

Neighbour-joining tree based on 16S rRNA gene sequences, showing the relationships between BAD-6T and type strains of other related species. NJ, ML and ME on one branch (•). X Numbers at nodes represent percentages of bootstrap support based on a maximum- likelihood analysis of 1000 resampled datasets. Values below $50 \%$ are not indicated at branch points. Bar, 0.02 substitutions per nucleotide position.

\section{Supplementary Files}

This is a list of supplementary files associated with this preprint. Click to download.

- Supplymentalmaterial.docx 